\title{
«GREEN» FINANCE AS A MARKER OF MODERN CORPORATE GOVERNANCE
}

\author{
Marharyta Prianyshnykova $^{1}$, Mykola Korolenko ${ }^{2}$ \\ ${ }^{l}$ postgraduate student, SESE «The Academy of Financial Management», Kyiv, Ukraine, e-mail: \\ margarita.pryan@gmail.com,ORCID: https://orcid.org/0000-0003-3871-9486 \\ ${ }^{2}$ postgraduate student, SESE «The Academy of Financial Management», Kyiv, Ukraine
}

In today's economic space, corporations play a significant role, so it is important to create an effective corporate governance structure. There are four approaches to corporate governance: internal, which consists in choosing a set of management mechanisms and distribution of functions that allow owners to control the activities of managers; external - company policy, values; legal - the principles governing rights, responsibilities; economic - a system of relations between owners and management, aimed at satisfying the interests of owners.

Due to rapid population growth and increasing world GDP, natural capital is being depleted, which in turn leads to negative social, economic and environmental changes.

Environmental pollution, resource depletion (deterioration of fresh water and arable land), climate change (natural disasters) all these factors affect the economy and lead to significant financial losses. Therefore, the issue of corporate social responsibility and the use of «green» financial instruments becomes relevant.

The aim is to highlight the essence of the concept of «green» bonds, their main purpose, the order of issue, international standards, country analysis and implementation in Ukraine.

The stereotype of a leader as a smart, cunning and clever businessman who starts yawning when it comes to environmental protection, charity and other social initiatives has sunk into oblivion, more and more businessmen in parallel with earning money, worry about the world around them and aim to improve it and get a positive image.

A radical shift is also dictated by the political agenda promoted by world leaders, which lays down new principles for the transformation of systemic processes of corporate governance, organization of production and activities in the capital market.

The basis of these principles are the desire of politicians and companies to solve climate problems that have no borders, because natural disasters caused by climate change can destroy any project and lead to irreversible consequences.

Climate change leads not only to hurricanes, floods and droughts, which cause billions in damage, but also to mass migration of people from subtropical areas to countries with more favorable climates, to numerous ethnic conflicts and socio- 
political phenomena, such as the «Arab Spring». Global warming, combined with the slowdown in the world economy and growing property inequality, can change both the economic and socio-political landscape of the world for the worse. That is why the political establishment of developed countries has raised the green theme, and the environment and carbon emissions from applied scientific problems have become the most powerful direction of international politics, able to significantly change the balance of power in the world economy and bring to power various parties, including openly populist, or promote the interests of private corporations and banks.

To control climate risks, Brussels has set quite ambitious goals. European Commission President Ursula von der Leyen dedicated her annual address to the European Parliament on this topic. The plan to overcome the crisis, announced by her on September 16, proposes measures for sustainable economic recovery that change the basic foundations of development [1].

By 2021, the European Commission plans to review EU climate and energy legislation to make it «valid for 55 years». It will specify the administrative rules that will help solve the tasks. It is planned to develop trade in $\mathrm{CO} 2$ emissions and renewable energy sources, increase energy efficiency, reform the taxation of operations related to the production, trade and use of energy resources [1].

The mission of the European «green» course is not limited to reducing emissions. We are talking about the systematic modernization of the economy, society and industry. "It is about creating a more sustainable world in which not only us but the next generation can live ... This requires a change in our attitude towards nature and how we build the world around us," said Ursula von der Leyen, representing the European Parliament. EU anti-crisis recovery plan called \#NextGenerationEU [1].

It is expected that in late 2021 - early 2022, the European Union will introduce a border tax on imports of goods with a high carbon footprint. This will deprive foreign suppliers of a possible advantage over European ones if they want to reduce costs and save on investment in modernization of production. Such tax practices are designed to encourage other countries to finance projects that do not have a detrimental effect on the climate and the environment.

Their implementation will bring a double benefit: first, the negative impact of industry on the environment will be reduced, and secondly, technology will pay off by the fact that when supplying goods to the EU, producers will be relieved of the obligation to pay additional taxes.

The carbon borders regulation mechanism will help ensure that others follow in Europe's footsteps. Such a prospect is already forcing the Ukrainian government and business to organize a national emissions trading system. Such a system will create 
conditions for their reduction through modernization of production, increase of energy efficiency and implementation of greenhouse gas absorption projects.

Without such measures, the biggest costs because of the new EU tax are suffer energy and oil and gas companies, metallurgists and mining companies, farmers, producers of mineral fertilizers, pulp and paper products and glass, who trade with Europe.

In order to avoid negative consequences, it is necessary to reform the world economy, ensure sustainable development and pave the way for a «green» economy.

We propose to divide the «green economy» into 7 sectors (Fig. 1).

\section{1. renewable energy sources}

- solar, wind, biofuels, etc.

\section{2. "green" buildings}

- energy saving technologies, etc.

\section{3. "green" transport}

- electric cars, alternative fuels, development of public transport, etc.

\section{4. water resources management}

- use of rainwater, water purification, etc.

waste disposal

- reuse, production from biodegradable materials, etc.

- reforestation, construction of parks, organic agriculture, soil restoration, etc.

\section{7. formation of a "green" generation}

- involvement in "green" activities, formation of education and conscious attitude

Fig. 1. Classification of sectors of the «green economy». The source is based on: [2, c.12].

Financing environmentally sustainable growth requires significant investments. It is the financial sector that is able to qualitatively ensure these changes. Currently, investments can be divided into useful and ordinary, and thanks to environmental projects, the issuer creates a positive image of a progressive company or state, which is focused on sustainable development.

The essence and current state of «green» bonds. Consider one of the most popular financial instruments - «green» bonds. «Green» bonds are an instrument of raising capital, a type of debt securities that certifies the loan relationship between the issuer and the bondholder and confirms the issuer's obligation to return to the bondholder its face value within the prescribed period and pay income on the bond, 
unless otherwise provided. Most «green» bonds are medium-term instruments (7-8 years). The main source of redemption of these bonds is cash receipts from assets. Technically, these bonds are no different from any other debt securities. Investors buy them, like other bonds, and the issuer receives money to implement their project. The main difference is only that such funds are targeted and can be spent only on projects with a positive impact on the environment [3, p.14]. Such initiatives are: projects of alternative energy sources, «clean» transport, projects of creation of «smart» houses and development of systems of effective utilization of waste. Funds can be used not only for new projects, but also for refinancing existing ones [4].

According to the mechanism of action, there are four main types of «green» bonds:

- standard bonds, the funds from which are directed to «green» projects (standard debt instrument with the right to claim against the issuer);

- «green» bonds tied to income: a debt obligation without the right of recourse to the issuer, in which the credit risk is tied to cash inflows, which is the subject of collateral through income, rewards, taxes, etc. Proceeds from the placement of such bonds are spent on "green" projects, which can be both related to the sources of such cash and not related to them;

- «green» project financing bonds: bonds with or without the right of recourse to the issuer are aimed at financing one or more «green» projects, for which the investor bears the risks associated with the projects;

- «green» securitized bonds: bonds secured by one or more "green" projects and including, but not limited to, bonds, asset-backed securities, mortgage-backed securities, etc. [5].

The main source of redemption of bonds is cash receipts from assets. This type of bond includes, for example, securitization of solar panels on roofs and / or securitization of energy efficient assets.

«Green» bonds first appeared on the financial market a little over 10 years ago, with the first such bonds being European Investment Bank bonds issued in 2007. They were intended to finance projects in the field of alternative energy sources and energy efficiency. The first bonds, marked as «green», appeared a year later, they were issued by the World Bank. Since then, this segment of the financial market has grown steadily, the average annual growth since 2007 is at 230 percent [6].

Let's highlight the main reasons for the rapid development of «green» bonds: awareness of the risks to humanity due to the unsatisfactory state of the environment, the attempt to direct financial resources to solve environmental problems; general greening of the world; the desire of business to look socially responsible.

The development of the market of «green» bonds is associated with the orientation of the largest investors to finance projects with sustainable development 
(achieving the UN Sustainable Development Goals, including a significant part is related to environmental issues).

One of the goals of European policy is to strengthen the EU's leadership in financing climate-safe investment projects and issuing sustainable «green» bonds.

In her annual address to MEPs, Ursula von der Leyen reaffirmed her intention to continue developing reliable standards for the issuance of «green» bonds at the level of European institutions. This is necessary to increase the confidence of investors, who must be sure that their capital goes to finance sustainable projects [1].

The head of the European Commission announced that $30 \%$ of the budget of the \#NextGenerationEU program in the amount of 750 billion euros will be raised through "green" bonds. About a third of these funds will go to hydrogen projects, environmentally friendly construction and development of a network of charging stations for electric vehicles (total - 1 million units) [1;7].

In 2014, the total issue of «green» bonds reached 36.6 billion dollars, in 2015 the figure increased to 41.8 billion dollars, and in 2016 to 87.2 billion dollars. In 2017, the issue was already 155.5 billion dollars. The growth of the segment slowed down only in 2018, following the results of the indicator at the level of 171.2 billion dollars, which is slightly higher than a year earlier [8, p.51]. In 2019, the market reached 258.9 billion dollars. The leaders in the issuance of «green» bonds were: the United States -51.3 billion dollars, the second place went to China - 31.3 billion dollars and France - 30.1 billion dollars [9].

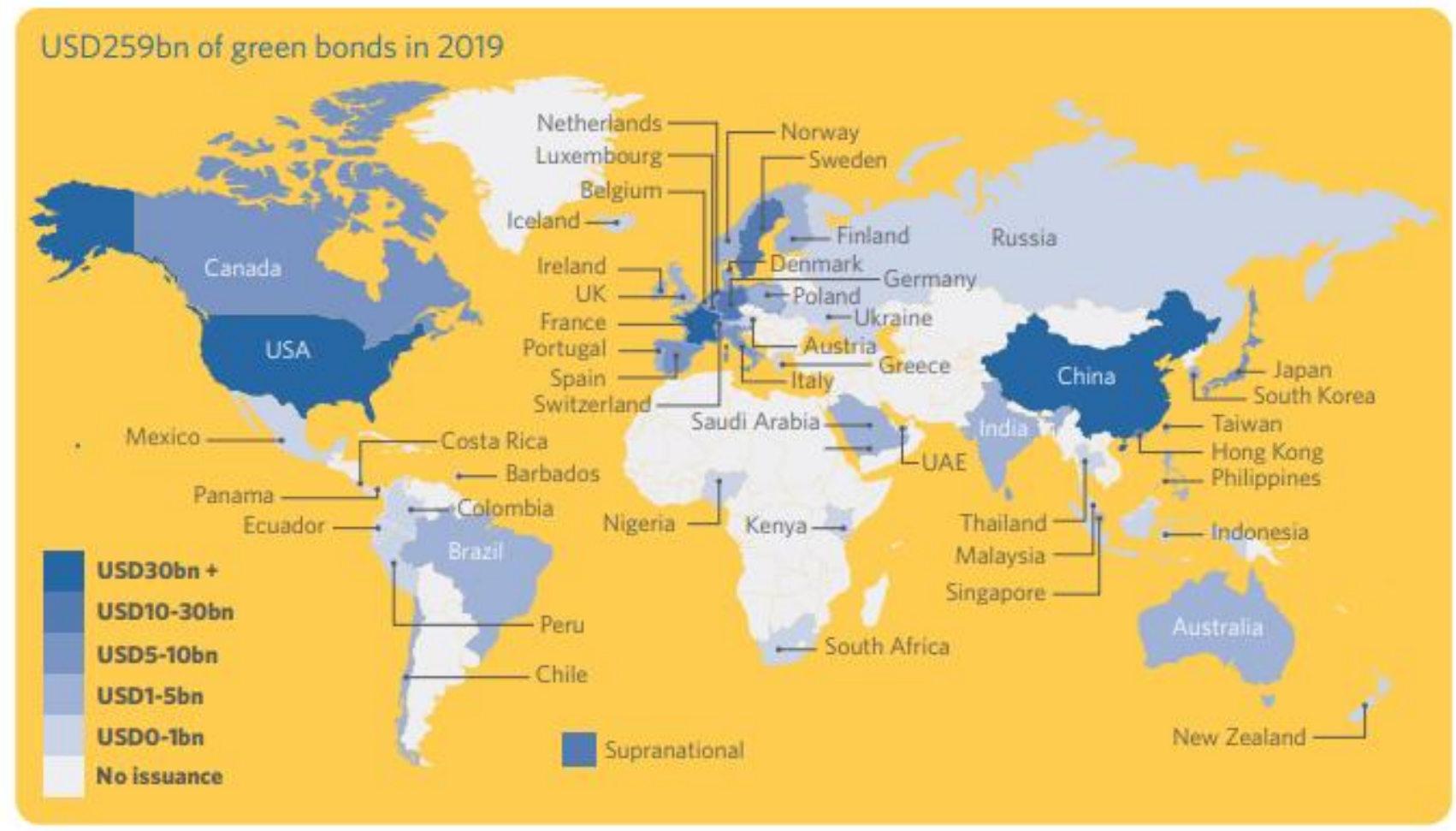

Fig. 2. Overview of the geographic market of «green» bonds

The source is based on: $[9, \mathrm{c} .3]$ 
According to the Climate Bonds Initiative, in the first half of 2020, the volume of «green» bonds decreased by $26 \%$ compared to the previous year, reaching a total of 91.6 billion dollars, such a slowdown is likely due to the ongoing COVID-19 pandemic [10, p.2].

Paradoxically, China, the world's second-largest emitter of «green» bonds, which is also the world's largest source of carbon emissions, has used «green» bonds to finance coal-fired power plants, while explaining this by the fact that the power plants built on this money are cleaner than those built earlier. The prevailing view among most rating agencies is that coal cannot be included in the green category. Among other things, China also issues bonds that are «green» only by Chinese standards and do not meet international environmental standards.

The popularity of «green» investments and their rapid growth naturally aroused the interest of fraudsters [11]. There is even a term «green camouflage», or «green wash», when the project, despite the «wrapper», does not reduce the negative impact on the environment. "Green camouflage» carries serious reputational risks. Many critics claim that the wide scope of what constitutes a «green» bond allows the organizations that issue them to utilize the capital raised for projects promoting sustainability that, in reality, have minimal climate impact. For example, the operator of China's Three Gorges Dam issued 840 million dollars in «green» bonds to be used for backing wind power projects in Europe. At a surface level, these bonds seem like a sustainable way to raise money and divert it to climate conscious projects. Looking deeper however, the Three Gorges Dam has been continuously cited as a source of water pollution and as damaging for the surrounding ecosystems. Regardless, investors rushed to buy bonds at face-value and overlooked the possible deeper environmental harms they may cause. This process, known as «green washing» has become a common practice among green bond issuers and is hurting the credibility of such investments. Another instance of greenwashing took place when the Chinese government issued Green Bonds to finance coal-efficiency projects that find ways to burn fossil fuels more effectively. Similarly, a Madrid-based oil and gas company named Repsol issued a set of «green» bonds that were used for making their oil refineries more efficient. Although technically still working towards energy efficiency, these projects are not helping the environment to the extent that issuers will often claim [12]. How big is the risk for Ukraine to face this phenomenon?

Attempts to «camouflage» will not be avoided, but if the domestic system is built on the basis of international standards and comply with the Green Bond Principles of the International Capital Markets Association (ICMA), if companies have a specialized ESG-rating and the regulator's policy to combat money laundering, then these risks will be minimal. 
Principles of «green» bonds. With the advent of «green» bonds in the financial market there was a need to create a single standard for their assessment of environmental friendliness and a mechanism for monitoring its implementation. The first attempt to develop such a standard was made in 2011, but its criteria were not suitable for evaluating all types of projects, and concerned only the field of wind energy generation. In 2015, the standard was expanded to a new version that has already covered several types of projects. However, work on a single standard is still underway. Today, the benchmark is the so-called Green Bonds Principles, developed by the International Capital Markets Association (ICMA) in 2014 along with other stakeholders. However, the principles of «green» bonds are voluntary.

«Green» bonds have a high level of transparency, so issuers must disclose the four key elements listed in the GBP Principles: the use of funds, the project evaluation and selection process, fund management and reporting [5].

1. The use of funds raised from the placement of bonds should be aimed exclusively at financing (refinancing) «green» projects.

The principles of «green» bonds cover four key areas of human concern: climate change, depletion of natural resources, biodiversity loss and air, water and soil pollution.

Recommended projects are:

-renewable energy (including generation, transmission, appliances and products);

—energy efficiency (eg in new and refurbished buildings, energy storage, district heating, smart grids, appliances and products);

-pollution prevention and control (including reduction of air emissions, control of greenhouse gases, soil remediation, waste reduction, waste recycling and energy / efficient energy emissions);

—environmentally sustainable management of living natural resources and land use (including organic agriculture; organic livestock; climate-oriented contributions from farms, such as crop protection or drip irrigation; ecological forestry, forest conservation or restoration of natural landscapes);

- conservation of terrestrial and aquatic biodiversity (protection of coastal, marine and watershed environments);

—clean transport (electric, hybrid, public, railway, non-motorized, multimodal transport, infrastructure for vehicles with clean energy and reduction of harmful emissions);

- sustainable water and wastewater management (including sustainable infrastructure for water treatment and / or drinking, wastewater treatment, river systems, flood mitigation) [13, p.4; 14, p. 3-4]. 
Any project that provides clear environmental improvements in these areas can be financed through the issuance of «green» bonds. The list, description and evaluation of such projects should be detailed in the information on the bond issue (issue prospectus).

2. In order to implement the principle of project evaluation and selection, the issuer must clearly define the objectives and define the procedure by which the issuer determines the compliance of projects with the categories of "green" projects, qualification criteria, including exclusion, avoidance or management of potential risks associated with projects. The principles declare a high level of transparency and encourage issuers to conduct an independent external evaluation of their own evaluation and selection processes [15].

3. The principle of cash management provides for a method of separate accounting of net income from the placement of bonds by crediting funds to separate accounts or portfolios. The Principles recommend that an auditor or other third party be involved to verify the method of internal accounting and the use of funds from the issuance of «green» bonds.

4. The issuer's reporting should reflect up-to-date information on the use of funds, a list and a brief description of the projects to which the funds are directed, indicating the amounts and expected impact of the projects. The principles recommend the use of qualitative and quantitative indicators of project effectiveness, as well as, if possible, to monitor the results achieved by these projects [16].

They are also encouraged to conduct an independent external evaluation of their own project evaluation and selection processes. To do this, the issuer may use any of the tools listed in the Principles:

- consultant review (separate independent opinion) - consulting support of a consultant or consulting firm with recognized expertise in financial projects related to environmental sustainability, which will review and evaluate the structure of the issuer's «green» bonds, usually in the form of a separate opinion or «independent opinion» of specialist before or after the issue $[17$, p.6];

— inspection or audit - a complete inspection of «green» bonds, the structure of their issue or underlying assets by a qualified third party (usually an audit firm), which is recognized, whose reputation is trusted and which is approved for such inspections for compliance with external and internal procedures of the issuer before and after the issue;

-certification - «green» bonds, their structure or the order of use of funds can be confirmed (certified) by the relevant accredited organization that carries out the relevant certification. However, so far the only globally recognized CBS (Climate Bonds Standart) certification still requires a qualified third party (such as an audit firm) to assess readiness for release; 
—rating - «green» bonds or their structure can receive a rating from the relevant rating agency or a specialized consulting firm. The rating of «green» bonds is given separately from the issuer's rating according to special so-called ESG indicators. ESG is an indicator that means information about the environmental and social impact, as well as corporate governance, which is increasingly used by investors in determining the investment attractiveness of the project [18].

In the future, the European Union plans to implement common standards for the issuance and placement of «green» bonds, which will be developed on the basis of the Principles and existing market practices, and can be used by issuers in any country to confirm the liquidity of these financial instruments.

Currently, the conditions set out in this document are followed by most of the world's issuers of «green bonds». For their observance, the investor judges the reliability of the issuer. In addition, the reliability of the issuer is confirmed by an independent party, usually reputable companies such as Deloitte, Moody's, the French company - Vigeo Eiris, the Norwegian - Cicero, Amsterdam - Sustainalytics, and so on.

The legal requirement for institutional investors to provide data on environmental factors in their investments has been adopted only in France in 2015. It is likely that the EU will further encourage its resident investors to invest green. At the same time, for the issuers themselves, the conclusion of the «green» bond market threatens additional costs for obtaining status from rating organizations and regulators.

Also, most «green» bonds in many countries have tax breaks, some have full tax exemptions, which in turn makes them more attractive than regular, taxable bonds. Tax breaks, of course, have been designed to increase the monetary incentive to address climate change and the transition to renewable energy.

Buyers of «green» bonds are mostly institutional investors, including pension funds, insurance companies and asset management companies. Significant funds also come from companies that are looking for «responsible» or «sustainable» places to place their money.

The largest issuer of «green» bonds is the World Bank. This organization funds environmental projects around the world, primarily in the United States and India. In India, in particular, with the proceeds from the sale of bonds, a branch of the World Bank has established the Rampur hydropower project, which aims to provide renewable energy to the power grid of North India. Also in this market are companies such as Apple and Bank of America [19].

Ukraine has significant potential for the development of «green» bonds. The launch of the market of «green» bonds will attract capital in various areas of energy efficiency in Ukraine, according to the State Agency for Energy Efficiency and 
Energy Saving of Ukraine. According to the International Finance Company (IFC), the launch of the «green» bond market will allow Ukraine to attract 73 billion dollars by 2030. In addition, attracting investment is necessary to meet the goals of the Energy Strategy of Ukraine until 2035 [20].

There are many examples in the world of the transition to «green» financing with the assistance of public authorities, which develop appropriate rules and recommendations for the market of «green» bonds. However, even in European countries, approaches to the organization of this market differ. Ukraine should use the experience of Poland, where state frameworks and procedures for issuing sovereign bonds have been introduced: the range of sectors, projects in which they could be implemented with the help of attracted financing depending on the degree of negative impact on the environment and climate; the procedure for selection of environmentally friendly projects has been established; approved step-by-step procedures for their financing, established procedures for reporting and disclosure of information on the target direction of funds and the real environmental impact of projects financed by «green» bonds; a separate treasury account was created to monitor the receipts and targeted use of funds raised from the issue of «green» bonds [21].

In the Law of Ukraine «On Amendments to Certain Legislative Acts of Ukraine on Simplification of Attracting Investments and Introduction of New Financial Instruments», adopted on June 19, 2020, Article 11 prescribes the concept of «green» bonds - bonds, prospectus (decision on the issue, and for government bonds of Ukraine - prospectus conditions) which provides (provides) the use of borrowed funds exclusively to finance the environmental project or a separate stage [22].

Article 18 prescribes the conditions for the operation of «green» bonds and persons who implement or finance an environmental project. The issue of «green» bonds can be carried out by a person who implements or finances an environmental project.

Funds from the placement of «green» bonds are used to finance and / or refinance the costs of the environmental project.

Persons implementing the project: the Council of Ministers of the Autonomous Republic of Crimea, the territorial community represented by a representative body of local self-government; the state of Ukraine in the person of authorized bodies; legal entity of private law.

Persons financing the project: specialized financial institution; a legal entity under private law, in particular a bank or other financial institution; international financial organization [22].

To effectively implement «green» bonds in Ukraine and gain the confidence of investors, it is necessary to apply the world practice of using this financial instrument, 
principles, standards and rules of their issuance and placement, which are declared by international associations, and on this basis to develop and implement legislation, guaranteeing the purpose of attracting investment in environmental, «green» projects.

Analyzing the experience of other countries, we can say that it is more fundamental. «Green» bonds include: social, blue and sustainable development bonds. That is, all possible categories, their essence and conditions are described in detail. Consider all categories, so «green» bonds are tools for raising capital for environmental projects, such as renewable energy, energy efficiency, clean transport, «green» buildings and balanced water management.

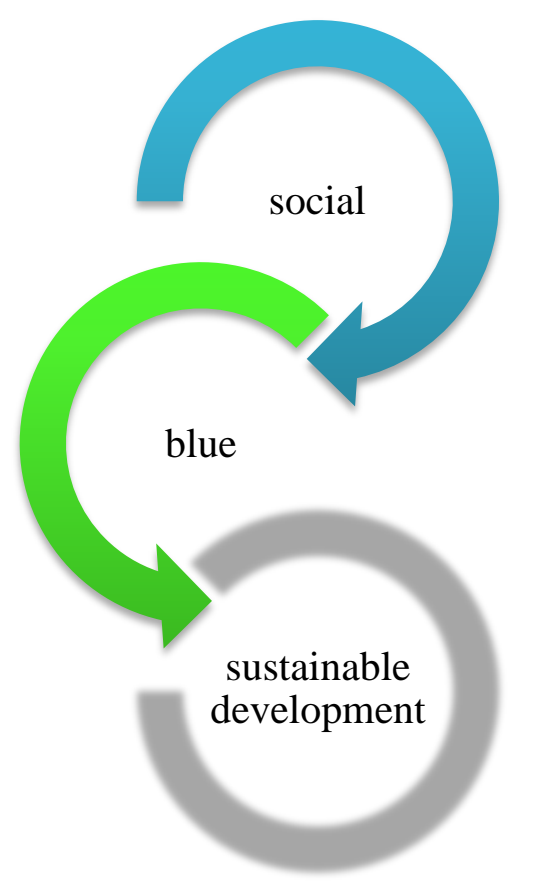

Fig. 3. Types of «green» bonds.

The source is based on: [23].

Social bonds are characterized by raising capital for projects with positive social outcomes, namely: health care, education and financial services, affordable housing and basic infrastructure, such as: sanitation, transport and clean drinking water.

Also a separate category are blue bonds, the world's first such bond issued in Seychelles in 2019, and this bond, in addition to the goals of improving the ecology of the oceans, also has goals to improve the economy of regions that depend to some extent on the use of marine resources [24].

There is a fourth type of sustainable development bond - a hybrid of «green» and social bonds.

Thus, «green» bonds are more targeted at large-scale business or country projects, while social bonds are more beneficial to communities. The experience of foreign countries shows that social projects with such investments have improved people's living conditions. 
For example, projects of socially affordable housing, construction of new logistics routes between remote areas, social transport with free travel, modernization of obsolete utilities, etc. Social bonds include the emergence of new jobs through the creation of environmental and social enterprises - from production to food [25].

There are many such clarifications for each type of bonds in different countries and, of course, they give hope that all projects of this kind will be developed in Ukraine [23].

Also, domestic business needs to think seriously about the not yet well-known to many in Ukraine abbreviation ESG - environment, social and governance environment, social responsibility and management. It is gaining popularity in the world and is gradually penetrating domestic practice. Adherence to ESG principles becomes a key condition for preserving the value of the business for shareholders and investors.

In addition, it can be a profitable investment: the value of companies that are responsible for the climate and the environment, among investors is growing rapidly. ESG principles integrated into business create long-term value. The crisis in which countries and companies have found themselves due to the coronavirus pandemic has shown that ESG can no longer be seen simply as a fashion trend or a purely image element in corporate governance. This is a matter of business survival and the same need as hand washing during a pandemic.

Despite the popularity of «green» finance and the growing demand from investors for environmental investment instruments, there are a number of problems in the development of the climate finance segment. First of all, it is the profitability and risks of green projects, for the financing of which bonds are issued. Unfortunately, most low-carbon and green investments in key sectors are not yet profitable, and the transition from carbon-intensive to green technologies can create financial and social risks [26]. Suffice it to say that the «yellow vests» protests in France, which arose because the government increased excise taxes on gasoline and diesel fuel to finance renewable energy projects, have been going on for more than a year [27].

Banks, despite accusations of financing the shadow economy, prefer to lend to oil and gas companies and traditional energy, as they understand the financial model, cash flows, efficiency and profitability of business, while renewable energy projects are often subsidized by governments and depend on government incentive programs in conditions where government debt is at very high levels and budget expenditures can be reduced. Climate its good, but credit risks and common sense have not yet been abolished. Financiers need government guarantees. The European Commission, for example, is still examining whether banks should be encouraged to finance sustainable industries by potentially easing EU rules on capital lending fees. Bankers 
will decide on the financing of environmental projects with regard to the governments and central banks of their countries, because to increase risky lending requires real grounds, otherwise banks will get new problems and increase the burden on their capital.

Andrea Enria, head of the European Banking Association (EBA), the supervisory body that coordinates banking rules in EU countries, said that: «any easing of capital requirements for green assets should be based on clear evidence that they are less risky than not green assets» [27].

So, just wearing green glasses so that ordinary glasses turn into emeralds of the magical land of $\mathrm{Oz}$, will not work. The success of «green» bonds will depend on the relationship and partnership of governments, banks, investment funds, regulators, as well as government co-financing of environmental projects [27].

Moreover, current incentives for green finance can be a source of potential weakness by adding risky assets to banks' balance sheets. The rules developed by the Basel Committee on Banking Supervision determine how much creditors can reduce their capital needs using their own internal models, but, firstly, there are quite strict requirements, and secondly, the rules will be fully implemented only by 2027 , and the current reporting of European banks on capital adequacy indicators shows signs of instability. And this is the second problem of «green» bonds.

The third problem is that so far, despite the growing interest in investing in clean energy, the opportunities and volumes of projects that fall under the standards of «green» bonds are not large enough. Coal is still the cheapest fuel, and the introduction of new coal-fired power plants continues, especially in emerging markets with rapidly growing demand for electricity.

In a number of developed countries, there is stagnation in capacity building with renewable energy sources, including through the use of solar and wind energy. This stagnation is caused by changes in subsidy policies or the uncertainty of government programs to support investment in clean energy. Partially green technologies are less green when tested, as the production of batteries or solar panels puts even more strain on the environment than ferrous or non-ferrous metallurgy, and low solar and wind energy flux densities and generation instability make it difficult to integrate green power plants into general energy sources.

The fourth problem is the lack of a methodology that helps to integrate the various opportunities associated with climate change into investment decisions [27].

Thus, the need for action on climate change is beyond doubt, and the financial sector plays a key role in the global economy, and without its participation, environmental projects will not be fully implemented. Financial flows and ways of transition to a low-carbon economy must go in parallel. 
But this transition must have a clear scientific basis without hype and political bias, without environmental mythology and unfounded PR. Otherwise, the world will receive negative climate change, and huge financial losses, and serious socio-political problems.

Crises give companies and countries a chance to rethink their strategy and policies, thus showing what was once considered indisputable is often a fallacy.

There is a growing awareness in the world that in the face of growing climate, environmental and social challenges, a stable functioning of the financial system is needed, which can only be ensured if the economy is transformed into a «green» one.

With the deterioration of the quality of natural, productive and human capital, which constitute the material base of financial capital, and the widening gap between them, the risks of new financial bubbles, large-scale and deep crises will increase significantly. Therefore, it is necessary to develop a new architecture of the future financial system, taking into account current global challenges to ensure sustainable development of the world economy.

The COVID-19 pandemic forces Ukrainian society and business to look at the world differently and to be more responsible for the environment. The consumer approach is a thing of the past, when the race for access to resources is replaced by a more conscious approach, which is to reduce the negative consequences that harm nature and the willingness to invest heavily in «green» initiatives.

This is facilitated by the strategic focus on deepening integration with the European Union, which plays an important role in Ukrainian reforms. The Association Agreement between Ukraine and the European Union provides for the harmonization of Ukrainian legislation with EU standards in the field of financial services, corporate governance and company activities. Therefore, the creation of a market for «green» bonds is an important step for Ukraine, which will direct investments to finance domestic environmental projects.

\section{References:}

1. Dolinchuk, S. (2020), "The nature of big business: how successful companies protect the climate and the environment”, Mind. URL : https://mind.ua/ru/publications/20215951-priroda-bolshogo-biznesa-kakuspeshnye-kompanii-zashchishchayut-klimat-i-ekologiyu.

2. Nikonorov, S. M. (2017), "Towards a green economy through green finance, the bioeconomy and sustainable development”, Russian Political Science, № 3, pp. 12-15.

3. Fatica, S. Panzica, R. and Rancan, M. (2020), "The pricing of green bonds: are financial institutions special?", SSRN. URL : https://ssrn.com/abstract=3623146.

4. Zachariah, R. (2016), "5 things to know about green bonds", The Economic Times. URL: https://economictimes.indiatimes.com/wealth/invest/5-things-to-know-about-green-

bonds/articleshow/50680956.cms?from=mdr.

5. Cheker, Ja. and Kulinich, V. (2019), "Environmental investments: will green bonds appear in Ukraine?", Mind. URL : https://mind.ua/ru/openmind/20202397-ekologicheskie-investicii-poyavyatsya-li-v-ukrainezelenye-obligacii.

6. Stahanova, A. (2019), “Green jerk”, Lenta.ru. URL : https://lenta.ru/articles/2019/04/09/green_world. 
7. Turp-Balazs, C. (2020), "State of the European Union 2020: Digital IDs, green investment, a European Bauhaus and a dig at Nord Stream 2", Emerging Europe. URL : https://emerging-europe.com/news/state-ofthe-european-union-2020-digital-ids-green-investment-a-european-bauhaus-and-a-dig-at-nord-stream-2/.

8. Jonesa, R. Bakerb, T. Huetc, K. Murphyd, L. and Lewisea, N. (2020), "Treating ecological deficit with debt: The practical and political concerns with green bonds", Geoforum. URL : https://reader.elsevier.com/reader/sd/pii/S0016718520301329?token=C716EA374141D75BF7132B0546AC C1AF28C62C1BD6B2DB66680DF8E52D4430DA1A985022E811B7DDA7DA45032306E658.

9. Almeida, M. (2019), "Green Bonds Global State Of The Market", Climate Bonds. URL : https://www.climatebonds.net/system/tdf/reports/cbi_sotm_2019_vol1_04d.pdf?file=1\&type=node\&id=4757 $7 \&$ force $=0$.

10.Green bond market summary H1 (2020), Climate Bonds. URL : https://www.climatebonds.net/system/tdf/reports/h1_2020_highlights_final.pdf?file=1\&type=node\&id=5421 $2 \&$ force $=0$.

11.Ludvigsen, P. (2015), Advanced topics in green bonds: Risks. Environmental Finance. URL : https://www.environmental-finance.com/content/analysis/advanced-topics-in-green-bonds-risks.html.

12.Rajwanshi, Y. and Babson, A. (2019), “Are Green Bonds as Good as They Sound?", BER staff. URL : https://econreview.berkeley.edu/are-green-bonds-as-good-as-they-sound/.

13.Green Bond Principles Voluntary Process Guidelines for Issuing Green Bonds June (2018), ICMA. URL : https://www.icmagroup.org/assets/documents/Regulatory/Green-Bonds/Green-Bonds-Principles-June-2018270520.pdf.

14.Berdiyev, U. (2020), "Towards Green Economy: Green bonds", International Finance and Accounting, vol. 2020, iss. 4, Article 22. URL : https://uzjournals.edu.uz/interfinance/vol2020/iss4/22.

15.Ivanic'ka, O. (2017), "Modern approaches to ensuring the transparency of financial activities of state institutions", Strategija rozvitku Ukraïni. URL : file://files/homefolder/MargaritaP/Downloads/13910-360531-SM.pdf.

16.Prospects for the development of the market of "green" bonds in Ukraine (2019), Energoreforma. URL : http://reform.energy/analitics/perspektivy-razvitiya-rynka-zelenykh-obligatsiy-v-ukraine-11404.

17.Dorfleitner, G. Utz, S. and Zhang, R. (2020), "The Pricing of Green Bonds: External Reviews and the Shades of Green", SSRN. URL : https://ssrn.com/abstract=3594114.

18. Aggarwal, N. (2018), "A practical insight into green bonds and ESG investing", Association of Corporate Treasurers. URL : https://www.treasurers.org/hub/treasurer-magazine/practical-insight-green-bonds-andesg-investing.

19.Mamchic, R. (2020), "Green bonds: a new promising instrument in the securities market", Finversia. URL : https://www.finversia.ru/publication/zelenye-obligatsii-novyi-perspektivnyi-instrument-na-rynketsennykh-bumag-71407.

20.The official site of Ministry of Finance (2019), "Green bonds can attract 73 billion in investments in Ukraine". URL : https://minfin.com.ua/ua/2019/06/07/38008397/.

21."Green" investments in sustainable development: world experience and Ukrainian context (2019), Razumkov Centre. URL : http://razumkov.org.ua/uploads/article/2019_ZELEN_INVEST.pdf.

22.The Verkhovna Rada of Ukraine (2020), The law of Ukraine "On amendments to some legislative acts of Ukraine to simplify investment attraction and introduction of new financial instruments". URL : https://zakon.rada.gov.ua/laws/show/738-20\#Text.

23.Tkachenko, M. (2020), "Investment Law: What's Wrong with the Green Bond Market", Comments.ua. URL : https://money.comments.ua/article/investments/zakon-o-privlechenii-investiciy-chto-ne-doskazano-vrynke-zelenyh-obligaciy-658198.html.

24.Bolliger, P. J. (2020), "Seychelles: Beyond dramatic imagery", Samudra Report. URL : http://aquaticcommons.org/27049/1/Sam_82_art01_Seychelles_Svein_Jentoft.pdf.

25.Gasanov, S. and Petruha, S. (2014), "Synopsis of world experience in building a food security system", ZhDTU. URL : http://library.ztu.edu.ua/doccard.php/97318.

26.Petruha, S. (2018), Derzhavne antikrizove reguljuvannja agrarnogo sektoru ekonomiki Ukraini [State anti-crisis regulation of the agricultural sector of Ukraine's economy], Centr uchbovoï literaturi, Kyiv, Ukraine.

27.Losev, A. (2019), "Green glasses for finance", Kommersant. URL : https://www.kommersant.ru/doc/4172142. 